\title{
Organochlorine Compounds in Marine Fish Samples of Bangladesh
}

\author{
Md. Mazharul Islam, Robiul Islam, Mohammad Shoeb and Nilufar Nahar \\ Department of Chemistry, University of Dhaka, Dhaka-1000, Bangladesh
}

\begin{abstract}
Bioaccumulation of organochlorine compounds in marine fish occurs as a result of environmental pollution through human activities such as industrial and agricultural waste discharge into water bodies. The main purpose of the present study is to evaluate the current status of the contamination level of organochlorine compounds such as 4,4'-DDT, 2,4'-DDT, 4,4'-DDE and 4,4'-DDD, in the fish samples of Bay of Bengal. A total of 25 marine fish samples of 17 species including Eleutheronema tetradactylum, Metapenaeus monoceros, Lates calcarifer, Harpodon nehereus, Pampus argenteus, Setipinna phasa, Leiognathus equulus, Tenualosa ilisha, Megalapsis cordyla, Parastromateus niger, Coilia ramcarati, Otolithoides pama, Arius maculatus, Paraplagusia bilineata, Strongylura leiura, Platycephalus indicus and Gudusia chapra were collected from three different local markets for determination of organochlorine compounds using SPD (solid phase dispersion) and QuEChERS (quick, easy, cheap, effective, rugged and safe) extraction methods, and finally analyzed by gas chromatograph equipped with electron capture detector (GC-ECD). The comparison between these two methods was also made and it was found that SPD method is more efficient for the extraction of total fat content and bioaccumulation of DDTs in fish samples compared to QuEChERS method. The percentage recovery of DDTs was found to be $65 \%-105 \%$. Limit of detection LOD and Limit of Quantification LOQ was found to be $0.10 \mathrm{ng} / \mathrm{g}$ and $0.30 \mathrm{ng} / \mathrm{g}$, respectively. Total amount of DDT was found in the range of 3.83-37.80 ng/g in SPD method and 4.51-20.40 ng/g in QuEChERS method. All fish samples contained DDTs less than MRL (maximum residue limit) value (5 $\mathrm{mg} / \mathrm{kg}$ according to the Codex Alimentarius Commission).
\end{abstract}

Key words: Bioaccumulation, organochlorine compounds, SPD, QuEChERS, GC-ECD and marine fish.

\section{Introduction}

Bangladesh is a densely populated country with a population of 160 million. Its financial condition largely depends on the production of different agricultural commodities. To meet the demand of food crops and to increase the food production, farmers are using different pest controlling compounds, called insecticides, herbicides and fungicides to protect plant and other agricultural products. Farming, fishing, mining, construction, forestry, urbanization and land pollution occurring near the water bodies create water quality problems and disruption in fish species [1]. DDT $\left(2,4^{\prime}\right.$-DDT and $4,4^{\prime}$-DDT), one of the major classes of organohalogen compounds, was widely used as pesticide and to control vector diseases. After

Corresponding author: Mohammad Shoeb, professor, research field: analytical and environmental chemist.
Stockholm convention the use of these organochlorine pesticides was banned worldwide including Bangladesh. However, there are reports that DDTs are being used in Bangladesh illegally and our previous study revealed that DDTs and their metabolites were present in fresh fish, dry fish and poultry meat samples $[2,3]$. DDTs can discharge into the water bodies during use and cause water pollution. However, their uptake in fish depends on the physicochemical properties of the chemicals and habitat, diet nature and the physiological properties of the organisms [4]. These types of chlorinated compounds are generally persisting in both the fresh and salt water and are resistant to photodegradation [5] and gradually accumulated in fish species depending on the octanol-water partition coefficient $\left(K_{\mathrm{ow}}\right)$ and transfer to the animal body lying in different level of the food chain [6]. Human beings are the sufferer in the food 
chain because they are on the top level. DDTs and their metabolites deposit in the fatty tissue of the body and cause different types of disorder like genetic, mutagenic teratogenic and other changes in the body cells and create different diseases including cancer. It was estimated that more than $90 \%$ of the DDT deposited in human population is came from food, especially from animal based fat such as fish [7]. DDT and its metabolites are lipophilic molecules which affect $\mathrm{Na}^{+}$or $\mathrm{K}^{+}$ion channel pumps in cell membrane of nervous systems [8]. As per our ongoing research on monitoring of organochlorine pesticides in fish samples [2,9], twenty five marine fish samples were analysed and reported here.

\section{Materials and Methods}

\subsection{Sampling Area}

Seventeen different species of marine fish samples $(n=25)$ were purchased randomly from three different local markets of Chittagong area near the coastal site of Bay of Bengal. Fish samples were labelled and preserved using ice and transported to laboratory. All the samples were kept at $-20{ }^{\circ} \mathrm{C}$ until analysis. Sampling location is shown in Fig. 1. Samples with their narrow range of length, width, weight and behavior are shown in Table 1. Some collected marine fish samples are shown in Fig. 2. Other physicochemical properties are shown in Table 2.

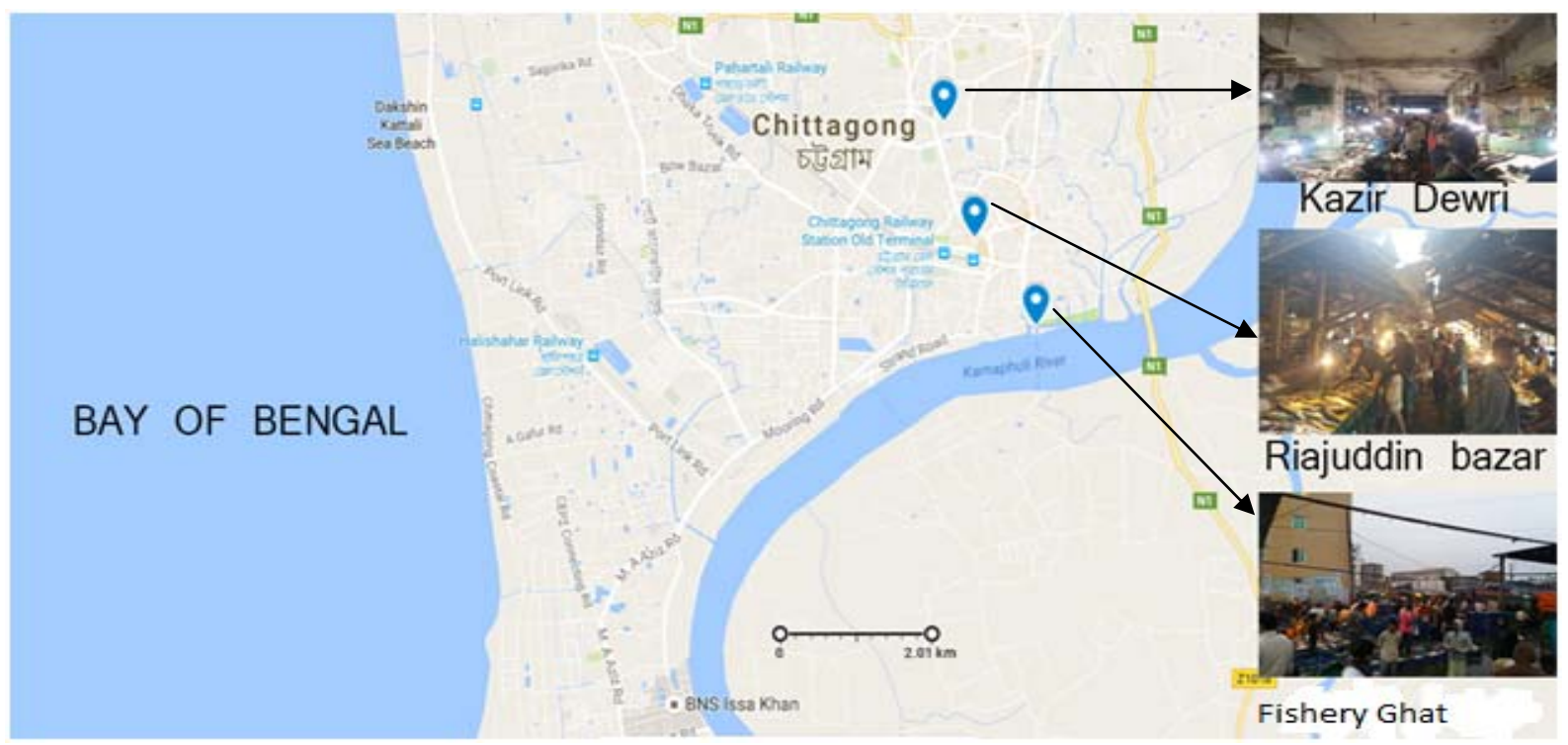

Fig. 1 Sampling locations.

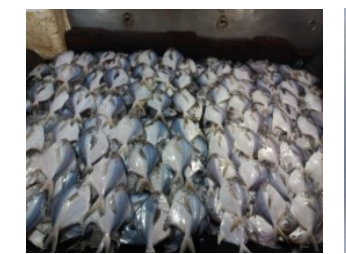

P. argenteus (Shadhachanda)

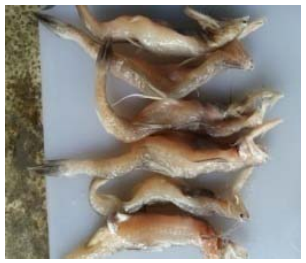

H. nehereus (Loitta)
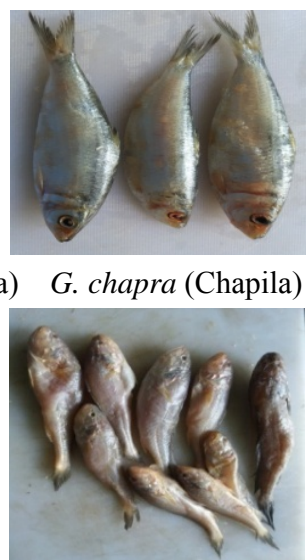

O. pama (Poa)

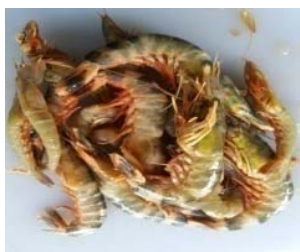

M. monoceros (Chingri)

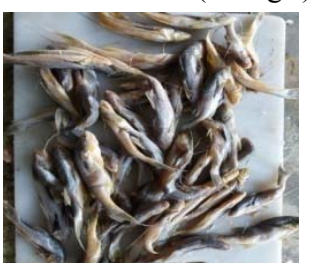

A. maculatus (Riksha)

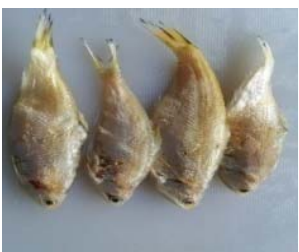

S. phasa (Faisha)

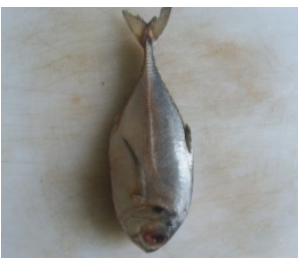

M. cordya (Surma)

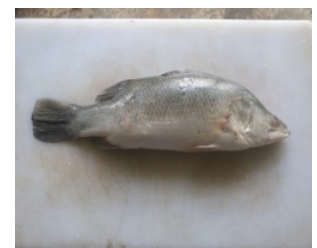

L. calcarifer (Koral)

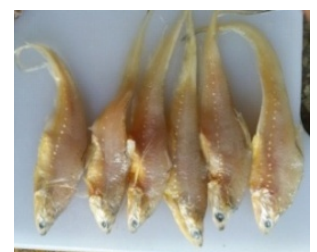

C. ramcarati (Olua)

Fig. 2 Some marine fish samples. 
Table 1 List of samples with narrow range of length, width, weight and behavior.

\begin{tabular}{|c|c|c|c|c|c|c|}
\hline Sampling area & English name (local name) & Scientific name & Length $(\mathrm{cm})$ & Width $(\mathrm{cm})$ & Weight $(\mathrm{g})$ & Behaviour \\
\hline \multirow{14}{*}{$\begin{array}{l}\text { Fishery Ghat } \\
\text { bazar }\end{array}$} & Long-finned croaker (Poa) & Otolithoides pama & 2.87 & 0.17 & 0.90 & benthopelagic \\
\hline & Spotted catfish (Riksha) & Arius maculatus & 14 & 3 & 139 & benthopelagic \\
\hline & Flat fish (Pata) & Paraplagusia bilineata & 22 & 5 & 40 & benthopelagic \\
\hline & Banded needlefish (Tuitta) & Strongylura leiura & 51 & 4 & 151 & benthopelagic \\
\hline & Gobi (Undurabailla) & Platycephalus indicus & 23 & 5 & 55 & demersal \\
\hline & Phasa (Phasa) & Setipinna phasa & $10-14$ & $3-5$ & $6-13$ & pelagic \\
\hline & Indian river shad (Chapila) & Gudusia chapra & 16 & 4.5 & 30 & pelagic \\
\hline & Barramundi (Koral) & Lates calcarifer & 26 & 9 & $>200$ & carnivore \\
\hline & Pink shrimp (Chingri ) & Metapenaeus monoceros & $9-16$ & $1.5-3$ & $12-14$ & benthic \\
\hline & Bamaloh (Loitta) & Harpodon nehereus & $17-20$ & $4-5$ & $22-36$ & benthopelagic \\
\hline & Cordyla scad (Surma) & Megalapsis cordya & 2.95 & 0.25 & 0.85 & pelagic \\
\hline & Black pomfret (Kalochanda) & Parastromateus niger & 26 & 16 & $>200$ & benthopelagic \\
\hline & Olua ( Olua) & Coilia ramcarati & $12-15$ & $3-5$ & $7-10$ & pelagic \\
\hline & White pomfret (Shadachanda) & Pampus argenteus & 18 & 11 & 89 & benthopelagic \\
\hline \multirow{7}{*}{ Reazuddin bazar } & Bamaloh (Loitta ) & Harpodon nehereus & 25 & 7 & $22-36$ & benthopelagic \\
\hline & Cordyla scad (Surma ) & Megalapsis cordya & 2.95 & 0.25 & 0.85 & pelagic \\
\hline & $\begin{array}{l}\text { Greater ponyfish } \\
\text { (Shadhachanda/Tekchanda) }\end{array}$ & Leiognathus equulus & 16 & 12 & 135 & benthopelagic \\
\hline & Indian salmon (Lakkha) & $\begin{array}{l}\text { Eleutheronema } \\
\text { tetradactylum }\end{array}$ & - & - & - & $\begin{array}{l}\text { varies } \\
\text { seasonally }\end{array}$ \\
\hline & Barramundi (Koral) & Lates calcarifer & 30 & 10 & 138 & carnivore \\
\hline & Gobi (Undurabailla) & Platycephalus indicus & 36 & 6 & $>200$ & demersal \\
\hline & Long-finned croaker (Poa) & Otolithoides pama & 2.87 & 0.17 & 0.90 & benthopelagic \\
\hline \multirow{7}{*}{$\begin{array}{l}\text { Kazir Daori } \\
\text { bazar }\end{array}$} & Gobi (Undurabailla ) & Platycephalus indicus & 42 & 7 & $>200$ & demersal \\
\hline & Barramundi (Koral) & Lates calcarifer & 32 & 12 & $>200$ & carnivore \\
\hline & White pomfret (Shadachanda) & Pampus argenteus & 18 & 11 & 89 & benthopelagic \\
\hline & Long-finned croaker (Poa) & Otolithoides pama & 2.87 & 0.17 & 0.90 & benthopelagic \\
\hline & Indian salmon (Lakkha) & $\begin{array}{l}\text { Eleutheronema } \\
\text { tetradactylum }\end{array}$ & - & - & - & $\begin{array}{l}\text { varies } \\
\text { seasonally }\end{array}$ \\
\hline & Bamaloh (Loitta) & Harpodon nehereus & 25 & 7 & $22-36$ & benthopelagic \\
\hline & Hilsha (Hilsha) & Tenualosa ilisha & 14 & 6 & 37 & pelagic-neritic \\
\hline
\end{tabular}

\subsection{Certified Chemical Reagents and Solvents}

Organochlorine compounds (4,4'-DDT, 2,4'-DDT, $4,4^{\prime}$-DDE and 4,4'-DDD) of $99 \%$ purity were purchased from Dr. Ehrenstorfer, Germany. The following analytical grade chemicals, reagents and solvents were used in this research work: anhydrous sodium sulphate (Scharlab S. L., 08181 Sentmenat Spain), silica sand (Kanto Chemical Co. Inc.), ethyl acetate (RCI Labscan Limited, USA), $n$-hexane (RCI Labscan Limited, USA), concentrated $\mathrm{H}_{2} \mathrm{SO}_{4}$ (Merck, Darmstadt, Germany), acetone (Sigma-Aldrich, France), silica gel (Merck KGaA, 64271 Dramstadt, Germany), $\mathrm{NaCl}$ and $\mathrm{H}_{2} \mathrm{SO}_{4}$ (98\%) were purchased from Merck, Germany.
2.3 Extractions and Clean-up Procedures of Fish Samples

Fish samples were extracted by two separate methods, i.e., SPD (solid phase dispersion) and QuEChERS (quick, easy, cheap, effective, rugged and safe). In SPD method, the muscle tissues of the fish samples were blended homogeneously. Blended sample (10.0 g) was taken into a pre-cleaned and dried mortar with silica sand $(10.0 \mathrm{~g})$ and anhydrous sodium sulphate $(30.0 \mathrm{~g})$. This powder (sample, sand and sodium sulphate) was taken in a $250 \mathrm{~mL}$ ground joint conical flask and extracted by shaking for 3 minutes successively with $60,20,20 \mathrm{~mL}$ ethyl acetate. The extracts were combined and filtered through anhydrous 
Table 2 Data of total fat or lipid, moisture and ash content in marine fish sample.

\begin{tabular}{|c|c|c|c|c|c|}
\hline \multirow{2}{*}{ Sampling area } & \multirow{2}{*}{ Sample name } & \multirow{2}{*}{ Moisture content $(\%)$} & \multirow{2}{*}{ Ash content $(\%)$} & \multicolumn{2}{|c|}{ Total fat content $(\%)$} \\
\hline & & & & SPD method & QuEChERS method \\
\hline \multirow{12}{*}{ Fishery Ghat bazar } & Poa & 80.89 & 0.63 & 0.80 & 0.40 \\
\hline & Riksha & 75.00 & 0.67 & 7.60 & 5.96 \\
\hline & Pata & 77.56 & 3.21 & 0.20 & not observed \\
\hline & Tuitta & 78.57 & 1.59 & 28.80 & not observed \\
\hline & Undurabaila & 78.43 & 0.98 & 25.13 & not observed \\
\hline & Faisha & 79.83 & 2.36 & 5.67 & 2.76 \\
\hline & Chapila & 71.43 & 6.01 & 3.60 & not observed \\
\hline & koral & 78.12 & 0.78 & 1.20 & not observed \\
\hline & Chingri & 80.80 & 1.60 & 4.73 & not observed \\
\hline & Loitta & 90.45 & 1.01 & 1.20 & not observed \\
\hline & Surma & 76.00 & 1.00 & 0.80 & 0.70 \\
\hline & Olua & 79.81 & 3.85 & 1.90 & not observed \\
\hline \multirow{7}{*}{ Riazuddin bazar } & Loitta & 86.29 & 1.01 & 0.93 & 0.53 \\
\hline & Surma & 79.84 & 1.61 & 25.46 & not observed \\
\hline & Shadhachanda & 73.81 & 0.79 & 10.47 & not observed \\
\hline & Lakkha & 77.60 & 0.80 & 2.40 & not observed \\
\hline & Koral & 75.55 & 1.48 & 1.40 & 0.93 \\
\hline & Undurabaila & 78.36 & 5.97 & 1.67 & 1.60 \\
\hline & Poa & 76.92 & 1.92 & 0.70 & 0.60 \\
\hline \multirow{6}{*}{ Kazir Dauri bazar } & Undurabaila & 79.10 & 1.49 & 0.67 & 0.23 \\
\hline & Koral & 78.48 & 1.89 & 0.50 & 0.37 \\
\hline & Shadhachanda & 77.64 & 1.18 & 2.60 & 2.17 \\
\hline & Poa & 77.78 & 1.58 & 25.86 & not observed \\
\hline & Lakkha & 80.64 & 0.85 & 2.80 & 0.67 \\
\hline & Loitta & 86.11 & 1.38 & 0.50 & not observed \\
\hline
\end{tabular}

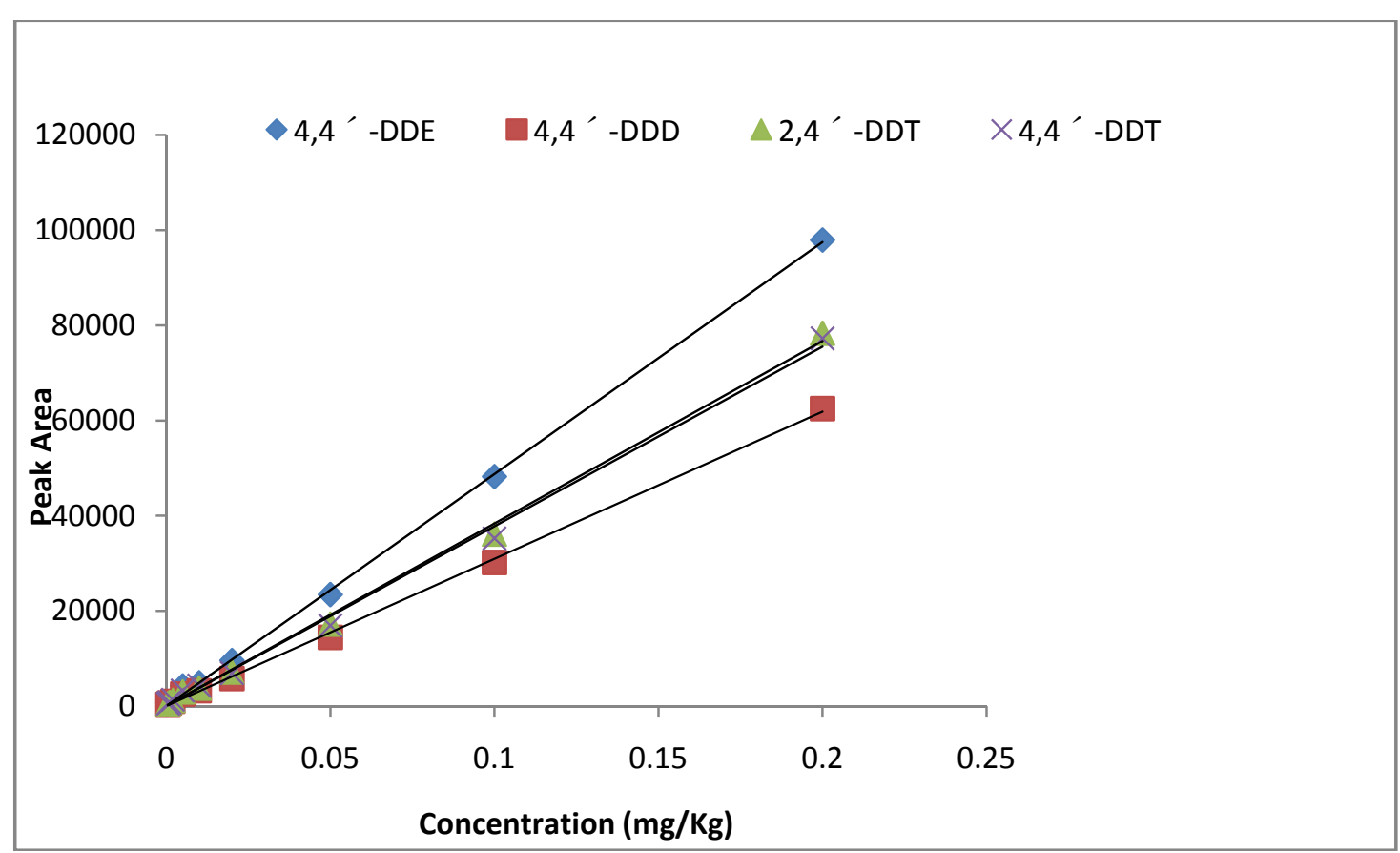

Fig. 3 Calibration curves of 4,4'-DDE and 4,4'-DDD; 2,4'-DDT and 4,4'-DDT. 
sodium sulphate. The filtrated extract was evaporated to dryness and weight of the fat was recorded. The solvent was exchanged from ethyl acetate to $n$-hexane by evaporation and the volume of the extract was adjusted up to $4 \mathrm{~mL}$. From this $2 \mathrm{~mL}$ concentrated extract was transferred quantitatively in a graduated test tube. Clean-up was carried out through silica gel:saturated sulphuric acid $(2: 1 \mathrm{~g} / \mathrm{g})$ column. The extract was then concentrated to $1 \mathrm{~mL}$ through the nitrogen gas evaporator. Then it was taken into a GC vial for injection to the GC-ECD.

In QuEChERS method, $10 \mathrm{~g}$ homogenized blended marine fish sample was taken in a $50 \mathrm{~mL}$ teflon centrifuge tube. And $20 \mathrm{~mL}$ ethyl acetate was added to it and shaken by hand for 1 minute and vortexed about 2 minutes. Anhydrous magnesium sulphate $(6.0 \mathrm{~g})$ and sodium chloride $(1.5 \mathrm{~g})$ were added and the mixture was again vortexed for 1 minute followed by centrifugation $(4,000 \mathrm{rpm}$ for 5 minutes). The supernatant was taken into a clean, dried and pre-weighted round bottom flask and the solvent was evaporated (below $40{ }^{\circ} \mathrm{C}$ ) to dryness by rotary vacuum evaporator. Then, the weight of total fat content was recorded. The solvent was exchanged from ethyl acetate to $n$-hexane by evaporation and the volume of the extract was adjusted up to $4 \mathrm{~mL}$. From this $2 \mathrm{~mL}$ concentrated extract was transferred quantitatively in a graduated test tube. Then, $2 \mathrm{~mL}$ saturated $\mathrm{H}_{2} \mathrm{SO}_{4}$ was added and shaken for 1 minute. Then the mixture was centrifuged for 10 minutes. Supernatant was taken using pasture pipette, kept into GC vial and analysed by GC-ECD.

\subsection{LOD, LOQ and Recovery Experiment}

At first, $100 \mathrm{mg} / \mathrm{L}$ primary standard solution was prepared by diluting proper amount of DDTs $(99 \%$ purity) in $n$-hexane and serially diluted to the different concentrated solution like 0.2, 0.1, 0.05, 0.02, 0.01, $0.005,0.002,0.001$ and $0.0005 \mathrm{mg} / \mathrm{kg}$. The limit of detection (LOD) was determined by injecting serially diluted mixtures of standard DDTs solution in GC-ECD. For LOD, the peak area of each standard was considered 3 times higher than the base line noise, i.e., signal to noise ratio was 3:1. LODs for DDT, DDE and DDD were found to be $0.10 \mathrm{ng} / \mathrm{g}$. The LOQ is the minimum concentration that can be quantified at a specified level of precision or accuracy (or both). For LOQ, the peak area of each standard was considered 10 times higher than the base line noise, i.e., signal to noise ratio was 10:1 and LOQ for fish samples DDTs residue analysis $0.30 \mathrm{ng} / \mathrm{g}$.

\subsection{Quantification of Residual Amount of DDTs by GC-ECD}

Quantification of residual amount of DDT and its metabolites were carried out by using reference standard solutions. The peaks of DDTs were obtained at retention time of around 10.12, 11.04, 11.20 and 11.69 minutes for 4,4'-DDE, 4,4'-DDD and 2,4'-DDT and 4,4'-DDT, respectively. Quantitative determination was carried out by comparing peak area of each DDT in the sample extract with that of standard solutions. From the calibration curve in Fig. 3, the amount of each DDT present in the sample extract was calculated (Tables 3 and 4).

In spiking and recovery experiment, a known amount of analyte was added (spiked) into the natural test sample matrix (Labeo rohita). Then, known amount (1.0 mL of $1.0 \mathrm{ppm}, 0.5 \mathrm{ppm}$ and $0.25 \mathrm{ppm})$ of standard DDTs solutions was spiked to the fish tissue (10 g each) and let the DDTs be absorbed into the samples. The samples were extracted and cleaned-up by following both the SPD and QuEChERS methods separately and made final volume $1.0 \mathrm{~mL}$. Blank samples were also analysed by GC-ECD. The percentage recoveries were calculated [2] for fish samples and found as 65\%-103\%, $76 \%-82 \%, 92 \%-105 \%$, and $86 \%-98 \%$ for $4,4{ }^{\prime}-D D T$, 2,4'-DDT, 4,4'-DDE, and 4,4'-DDD respectively. 
Table 3 Residual amounts of DDTs in the marine fish samples (SPD method).

\begin{tabular}{|c|c|c|c|c|c|c|c|}
\hline \multirow[t]{2}{*}{ Collecting area } & \multirow{2}{*}{-Sample name } & \multicolumn{5}{|c|}{ Amount of DDT and its metabolites (ng/g) (average \pm SD) } & \multirow{2}{*}{$-\frac{4,4^{\prime}-\mathrm{DDT}}{\sum \mathrm{DDT}}$} \\
\hline & & $4,4^{\prime}-\mathrm{DDE}$ & $4,4^{\prime}-\mathrm{DDD}$ & $2,4^{\prime}-\mathrm{DDT}$ & $4,4^{\prime}$-DDT & $\Sigma \mathrm{DDT}$ & \\
\hline \multirow{13}{*}{$\begin{array}{l}\text { Fishery Ghat } \\
\text { bazar }\end{array}$} & Chapila & $5.14 \pm 0.45$ & $1.05 \pm 0.24$ & $2.46 \pm 0.12$ & $3.09 \pm 0.15$ & 11.76 & 0.26 \\
\hline & Chingri & $0.30 \pm 0.33$ & BDL & $3.30 \pm 0.44$ & $1.10 \pm 0.13$ & 4.72 & 0.23 \\
\hline & Faisha & $4.06 \pm 0.39$ & $0.31 \pm 0.27$ & $3.31 \pm 0.34$ & $3.59 \pm 0.59$ & 11.28 & 0.31 \\
\hline & Koral & $3.42 \pm 0.62$ & $5.78 \pm 0.17$ & $3.33 \pm 0.33$ & $4.46 \pm 0.76$ & 17.00 & 0.26 \\
\hline & Loitta & $2.90 \pm 0.23$ & $0.36 \pm 0.13$ & $2.96 \pm 0.32$ & $4.01 \pm 0.44$ & 10.25 & 0.39 \\
\hline & Pata & $1.76 \pm 0.29$ & $2.00 \pm 0.24$ & $5.60 \pm 0.22$ & $2.38 \pm 0.33$ & 11.76 & 0.20 \\
\hline & Poa & $0.44 \pm 0.83$ & $0.81 \pm 0.0$ & $4.68 \pm 0.42$ & $1.48 \pm 0.25$ & 7.44 & 0.19 \\
\hline & Riksha & $0.28 \pm 0.38$ & $0.11 \pm 0.01$ & $3.37 \pm 0.36$ & $3.20 \pm 0.27$ & 6.98 & 0.45 \\
\hline & Surma & $3.16 \pm 0.43$ & $0.36 \pm 0.05$ & $6.75 \pm 0.61$ & $4.90 \pm 0.28$ & 15.18 & 0.32 \\
\hline & Tuitta & $4.31 \pm 0.51$ & $7.93 \pm 0.09$ & $3.34 \pm 0.52$ & $3.92 \pm 0.20$ & 19.52 & 0.20 \\
\hline & Olua & $2.31 \pm 0.24$ & $4.14 \pm 0.35$ & $1.49 \pm 0.13$ & $6.60 \pm 1.00$ & 14.54 & 0.45 \\
\hline & Undurabaila & $2.03 \pm 0.27$ & $2.48 \pm 0.30$ & $2.49 \pm 0.07$ & $3.01 \pm 0.18$ & 10.01 & 0.30 \\
\hline & RSD (\%) & $3.37-18.61$ & $1.17-19.88$ & $3.02-15.56$ & $5.23-17.33$ & - & - \\
\hline \multirow{7}{*}{$\begin{array}{l}\text { Reazuddin } \\
\text { bazar }\end{array}$} & Koral & $0.54 \pm 0.54$ & $0.98 \pm 0.22$ & $1.657 \pm 0.139$ & $1.35 \pm 0.21$ & 4.53 & 0.29 \\
\hline & Lakkha & $2.79 \pm 0.14$ & $0.35 \pm 0.38$ & $2.187 \pm 0.145$ & $2.58 \pm 0.42$ & 7.92 & 0.32 \\
\hline & Loitta & $0.58 \pm 0.32$ & $6.75 \pm 0.27$ & $5.331 \pm 0.665$ & $1.52 \pm 0.17$ & 14.19 & 0.10 \\
\hline & Poa & $0.22 \pm 0.36$ & $0.58 \pm 0.10$ & $1.667 \pm 0.136$ & $1.35 \pm 0.12$ & 3.83 & 0.35 \\
\hline & Shadhachanda & $7.18 \pm 1.21$ & $6.35 \pm 0.19$ & $5.976 \pm 0.367$ & $5.92 \pm 0.24$ & 25.44 & 0.23 \\
\hline & Undurabaila & $31.03 \pm 1.48$ & $4.89 \pm 0.24$ & $4.458 \pm 0.451$ & $2.86 \pm 0.26$ & 43.24 & 0.06 \\
\hline & RSD (\%) & $4.77-16.93$ & $1.17-19.88$ & $6.14-12.47$ & $3.63-16.2$ & - & - \\
\hline \multirow{8}{*}{$\begin{array}{l}\text { Kazir Daori } \\
\text { bazar }\end{array}$} & Koral & $1.26 \pm 0.17$ & $1.66 \pm 0.16$ & $1.03 \pm 0.12$ & $1.28 \pm 0.18$ & 5.25 & 0.24 \\
\hline & Lakkha & $6.39 \pm 0.31$ & $2.95 \pm 0.34$ & $5.43 \pm 1.07$ & $5.32 \pm 0.47$ & 20.11 & 0.26 \\
\hline & Poa & $1.19 \pm 0.62$ & $0.28 \pm 0.17$ & $6.33 \pm 0.59$ & $1.54 \pm 0.23$ & 9.35 & 0.16 \\
\hline & Shadhachanda & $0.94 \pm 0.28$ & $1.36 \pm 0.13$ & $5.26 \pm 0.90$ & $1.94 \pm 0.30$ & 9.51 & 0.20 \\
\hline & Surma & $2.60 \pm 0.12$ & $2.92 \pm 0.32$ & $4.59 \pm 0.13$ & $4.75 \pm 0.14$ & 14.86 & 0.31 \\
\hline & Undurabaila & $3.53 \pm 0.38$ & $0.63 \pm 0.03$ & $6.50 \pm 1.09$ & $3.37 \pm 0.20$ & 14.05 & 0.23 \\
\hline & Loitta & $20.07 \pm 0.65$ & $5.89 \pm 0.42$ & $8.15 \pm 0.89$ & $3.68 \pm 0.33$ & 37.80 & 0.09 \\
\hline & RSD (\%) & $3.26-13.62$ & $1.17-19.88$ & $2.77-19.72$ & $3.10-15.76$ & - & - \\
\hline
\end{tabular}

Table 4 Residual amounts of DDTs in the marine fish samples collected from Chittagong area (QuEChERS method).

\begin{tabular}{|c|c|c|c|c|c|c|}
\hline \multirow{2}{*}{$\begin{array}{l}\text { Sample name } \\
\text { (location) }\end{array}$} & \multicolumn{5}{|c|}{ Amount of DDT and its metabolites (ng/g) (average \pm SD) } & \multirow{2}{*}{$\frac{4,4^{\prime}-\mathrm{DDT}}{\Sigma \mathrm{DDT}}$} \\
\hline & 4,4'-DDE & 4,4'-DDD & $2,4^{\prime}$-DDT & 4,4'-DDT & $\Sigma$ DDT & \\
\hline Faisha (FG) & $2.55 \pm 0.09$ & $0.95 \pm 0.14$ & $3.27 \pm 0.22$ & $8.76 \pm 0.40$ & 15.54 & 0.56 \\
\hline Poa $(\mathrm{FG})$ & $1.23 \pm 0.18$ & $0.16 \pm 0.09$ & $2.82 \pm 0.45$ & $3.16 \pm 0.21$ & 7.39 & 0.42 \\
\hline Riksha (FG) & $3.21 \pm 0.45$ & $0.79 \pm 0.14$ & $4.90 \pm 0.68$ & $10.57 \pm 1.11$ & 19.47 & 0.54 \\
\hline Surma (FG) & $2.83 \pm 0.24$ & $0.69 \pm 0.03$ & $4.80 \pm 0.71$ & $12.07 \pm 1.37$ & 20.40 & 0.59 \\
\hline Koral (KD) & $0.68 \pm 0.08$ & $1.77 \pm 0.17$ & $2.38 \pm 0.43$ & $1.94 \pm 0.30$ & 6.77 & 0.28 \\
\hline Lakkha (KD) & $2.56 \pm 0.29$ & $0.71 \pm 0.01$ & $3.23 \pm 0.58$ & $3.62 \pm 0.29$ & 10.12 & 0.35 \\
\hline Shadhachanda (KD) & $0.39 \pm 0.05$ & $0.13 \pm 0.01$ & $2.11 \pm 0.30$ & $1.87 \pm 0.24$ & 4.51 & 0.41 \\
\hline Undurabaila (KD) & $0.92 \pm 0.09$ & $0.30 \pm 0.05$ & $3.32 \pm 0.23$ & $4.11 \pm 0.30$ & 8.67 & 0.47 \\
\hline Koral (RB) & $1.51 \pm 0.03$ & $0.45 \pm 0.08$ & $2.79 \pm 0.43$ & $4.03 \pm 0.45$ & 8.78 & 0.45 \\
\hline Loitta (RB) & $2.01 \pm 0.28$ & $0.78 \pm 0.15$ & $6.48 \pm 0.08$ & $8.35 \pm 0.15$ & 17.62 & 0.47 \\
\hline Poa (RB) & $1.03 \pm 0.18$ & $0.17 \pm 0.04$ & $1.08 \pm 0.13$ & $2.30 \pm 0.22$ & 4.59 & 0.50 \\
\hline Undurabaila (RB) & $2.46 \pm 0.26$ & $1.08 \pm 0.14$ & $2.88 \pm 0.39$ & $4.79 \pm 0.73$ & 11.23 & 0.42 \\
\hline RSD (\%) & $2.446-17.363$ & 2.313-19.905 & $1.375-18.213$ & $1.833-5.861$ & - & - \\
\hline
\end{tabular}

Sampling area note: $\mathrm{FG}=$ Fishery Ghat bazar; $\mathrm{RB}=$ Reazuddin bazaar; $\mathrm{KD}=$ Kazir Dauri bazar. 


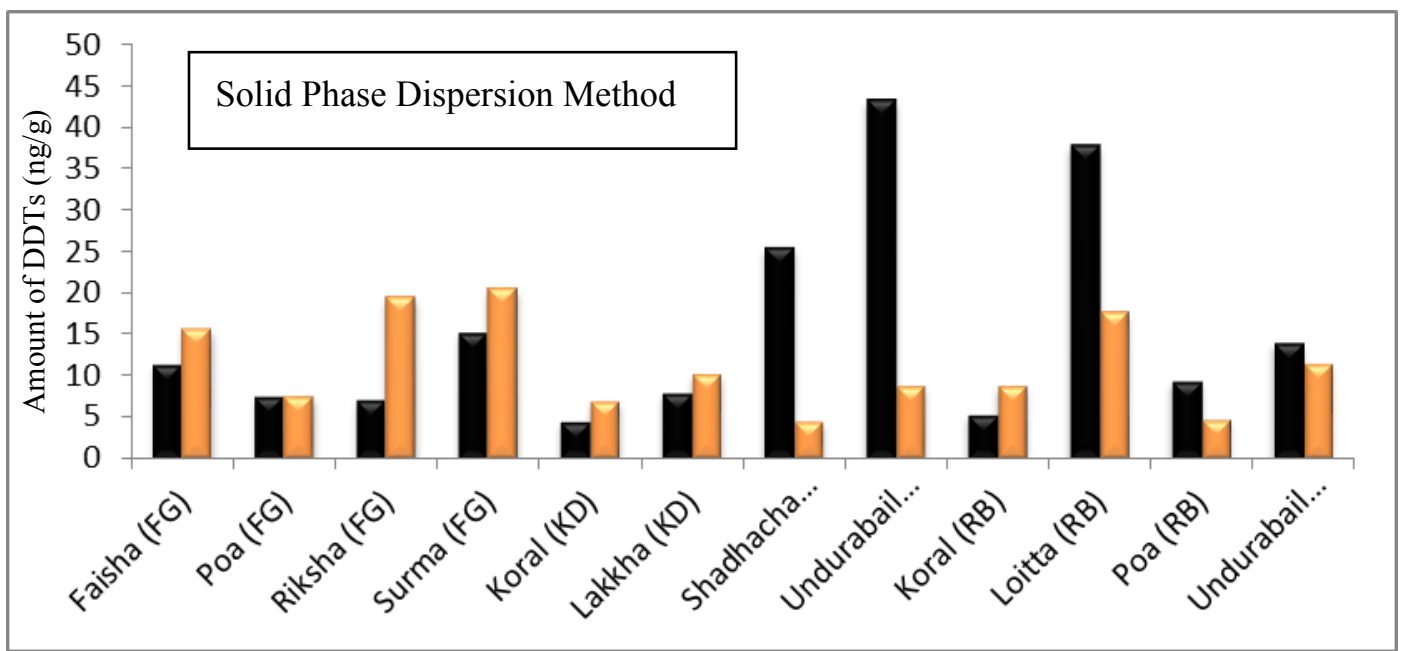

Fig. 4 Comparison of total DDTs content in fish sample through the SPD and QuEChERS method.

\section{Results and Discussion}

In this study, marine fish samples were analysed for the quantitative determination of organochlorine compounds (DDTs). Two extraction methods, i.e., the SPD and QuEChERS were used and finally analysed by GC-ECD. The highest amount of fat content was found in Tuitta fish (S. leiura) (28.8\%) and the lowest amount in pata fish (P. bilineata) $(0.20 \%)$ by SPD method whereas in the QuEChERS method, the highest amount of fat content was found in riksha ( $A$. maculatus) fish (5.96\%) and the lowest amount in the undurabaila ( $P$. indicus) fish $(0.23 \%)$. The results indicated that the SPD method is more efficient than that of QuEChERS method for the extraction of total fat content from fish samples. The highest amount of 4,4'-DDT, 2,4'-DDT, 4,4'-DDE, and 4,4'-DDD contents was found as $31.03 \mathrm{ng} / \mathrm{g}$ in Undurabaila $(P$. indicus) fish, $7.93 \mathrm{ng} / \mathrm{g}$ in Tuitta (S. leiura) fish, 8.15 $\mathrm{ng} / \mathrm{g}$ in Loitta (H. nehereus) fish and $6.60 \mathrm{ng} / \mathrm{g}$ in Ulua (C. ramcarati) fish and the lowest amount was found as $0.22 \mathrm{ng} / \mathrm{g}$ in Poa fish, Below detection limit in Chingri (M. monoceros), $1.02 \mathrm{ng} / \mathrm{g}$ in Koral ( $L$. calcarifer) fish and $1.11 \mathrm{ng} / \mathrm{g}$ in Chingri ( $M$. monoceros) fish, respectively which were extracted by the SPD method. The highest amount of 4,4'-DDT, 2,4'-DDT, 4,4'-DDE, and 4,4'-DDD contents was found as $3.21 \mathrm{ng} / \mathrm{g}$ in Riksha (A. maculatus) fish,
$1.773 \mathrm{ng} / \mathrm{g}$ in Koral (L. calcarifer) fish, $6.48 \mathrm{ng} / \mathrm{g}$ in Loitta (H. nehereus) fish and $12.07 \mathrm{ng} / \mathrm{g}$ in Surma (M. cordya) fish and the lowest amount was found as 0.39 $\mathrm{ng} / \mathrm{g}$ in Shadhachanda (P. argenteus) fish, $0.13 \mathrm{ng} / \mathrm{g}$ in shadhachanda (P. argenteus) fish, $1.08 \mathrm{ng} / \mathrm{g}$ in Poa (O. pama) fish and $1.87 \mathrm{ng} / \mathrm{g}$ in Shadhachanda ( $P$. argenteus), respectively which were extracted by the QuEChERS method was shown in Fig. 4. The comparative data indicate that the SPD method is more efficient for the quantitative determination of DDTs from fish samples than QuEChERS method although the QuEChERS method is cheaper, less time consuming, environmental friendly and more economic than SPD method. Again, the value of ratio of 4,4'-DDT to total DDT is below 0.5 in most of the fish samples, which implies that the DDTs were used in very past time but not recent or ongoing. All fish samples contained DDTs less than the MRL values (5 $\mathrm{mg} / \mathrm{kg}$ according to the Codex Alimentarius, 1993) [10]. The results indicated that consumptions of these marine fishes are safer in the context of DDTs contamination but continuous consumption of such fishes may cause a threat to human health as a result of bio magnifications. This study also reveals that DDTs are still existing in the marine environment although the use of the pesticide was banned in Bangladesh. 


\section{Conclusions}

The present study compared the efficiency between two methods, i.e., SPD and QuEChERS for the extraction of organochlorine compounds from marine fish samples, and SPD method was found more efficient than QuEChERS method. For most of the samples, the level of DDTs was found below the MRL value analysed by both methods. But excess intake of contaminated fishes may impose a health risk factor, especially fishers and coastal communities who may eat fishes every day. Again, the ratio of $4,4^{\prime}$-DDT/ $\sum$ DDTs was in the range of 0.06-0.45 which implies that the exposure of DDT is not for the recent or ongoing use. The present research recommends that the sources of DDTs in the vicinity of the Bay of Bengal should be strictly monitored for protecting the contamination of marine ecosystem along with fish community.

\section{Acknowledgements}

Authors are grateful to ISP (International Science Program), Uppsala, Sweden, HEQEP (Higher Education Quality Enhancement Project) and Ministry of Science and Technology, Government of the People's Republic of Bangladesh for financial supports.

\section{References}

[1] Akan, J. C., Abdulrahman, F. I., and Chellube, Z. M.
2014. "Organochlorine and Organophosphorus Pesticide Residues in Fish Samples from Lake Chad, Baga, North Eastern Nigeria." International Journal of Innovation, Management and Technology 5 (2): 87-92.

[2] Hossain, M. A., Shoeb, M., and Nahar, N. 2016. "DDT and Its Metabolites in Fresh Water Fish Samples." J. Food Sci. and Engineering 6: 344-50.

[3] Shoeb, M., Mahim, A., Mamun, M. I. R., and Nahar, N. 2016. "Organochlorine Pesticide Residues in Poultry Meats of Bangladesh.” Croat. J. Food Sci. Technol. 8 (1): 30-3. 10.17508/CJFST.2016.8.1.04.

[4] Van Leeuwen, C. J., and Vermeire, T. G. 2007. Risk Assessment of Chemicals: An Introduction. The Netherlands: Springer.

[5] Shokrzadeh, M., Saeedi, S. S., Saravi, Y., and Zehtab, Y. 2009. "Lindane Residues in Cultivated Cucumber and in the Most Consumed Fish in Caspian Sea (Iran)." Toxicology and Industrial Health 25 (8): 517-23.

[6] Arnot, J., and Gobas, F. A. P. C. 2003. "A Generic QSAR for Assessing the Bioaccumulation Potential of Organic Chemicals in Aquatic Food Webs.” QSAR Comb. Sci. 22: 337-45.

[7] Chung, S. W. C., Kwong, K. P., and Yau, J. C. W. 2008. "Dietary Exposure to DDT of Secondary Students in Hong Kong." Chemosphere 73: 65-9.

[8] Esmaili Sari, A. 2002. Pollution, Health and Environmental Standards. Tehran, Iran: Naghshe Mehr Press.

[9] Zamir, R., Hossain, M., Shoeb, M., Mosihuzzaman, M., and Nahar, N. 2013. "Organochlorine Pesticides in Three Fish Samples.” The Dhaka Univ. J. Sci. 61 (2): 215-6.

[10] Codex Alimentarius. 1993. "Pesticides Residues in Food, Joint FAO/WHO Food Standards Programme." Codex Alimentarius Commission, 23. 